\title{
Tropical Zoology
}

\section{Diversity of iron cave-dwelling mygalomorph spiders from Pará, Brazil, with description of three new species (Araneae)}

\author{
Rafael Fonseca-Ferreira, Robson de Almeida Zampaulo \& José Paulo Leite \\ Guadanucci
}

To cite this article: Rafael Fonseca-Ferreira, Robson de Almeida Zampaulo \& José Paulo Leite Guadanucci (2017) Diversity of iron cave-dwelling mygalomorph spiders from Pará, Brazil, with description of three new species (Araneae), Tropical Zoology, 30:4, 178-199, DOI: 10.1080/03946975.2017.1367590

To link to this article: https://doi.org/10.1080/03946975.2017.1367590

曲 Published online: 26 Sep 2017.

Submit your article to this journal $₫$

Џ Article views: 113

View Crossmark data ¿ 


\title{
Diversity of iron cave-dwelling mygalomorph spiders from Pará, Brazil, with description of three new species (Araneae)
}

\author{
Rafael Fonseca-Ferreira ${ }^{\mathrm{a}, \mathrm{b}^{*}}$, Robson de Almeida Zampaulo ${ }^{\mathrm{c}}$ and José Paulo Leite Guada- \\ nucci $^{\mathrm{d}}$ \\ ${ }^{a}$ Pós-graduação em Biologia Comparada, Faculdade de Filosofia, Ciências e Letras de Ribeirão \\ Preto, Universidade de São Paulo, Avenida Bandeirantes 3900, 14040-901, Ribeirão Preto-SP, \\ Brazil; ${ }^{b}$ Laboratório de Estudos Subterrâneos, Departamento de Ecologia e Biologia Evolutiva, \\ Universidade Federal de São Carlos, via Washington Luiz Km 235, 13565-905, São Carlos-SP, \\ Brazil; ' ${ }^{\circ}$ Gerencia de Licenciamento Ambiental e Espeleologia, Vale SA, Avenida Doutor Marco \\ Paulo Simon Jardim, 34006-200 Nova Lima-MG, Brazil; ${ }^{d}$ Departamento de Zoologia, Instituto de \\ Biociências, Universidade Estadual Paulista, Avenida 24A 1515, 13506-900 Rio Claro-SP, Brazil
}

(Received 1 April 2017; accepted 11 August 2017; first published online 26 September 2017)

\begin{abstract}
Mygalomorph spiders are rarely found in caves and most of the records appear as accidental or restricted to small populations. The present study took place in iron formations in Carajás region, southeastern Pará state, eastern Brazilian Amazon rainforest. Each cave was sampled twice: dry season (from May to October) and wet season (from November to April). Of the 242 caves sampled, we found mygalomorphs in 98 (40\%). The survey yielded 254 specimens, 223 (87.8\%) juveniles. Of the 14 species recorded, nine were represented by adults: Dolichothele tucuruiense (Guadanucci, 2007), Hapalopus aymara Perdomo, Panzera \& Pérez-Miles, 2009, Acanthoscurria geniculata (CL Koch, 1841), Theraphosa blondi (Latreille, 1804), Nhandu coloratovillosus (Schmidt, 1998), Fufius minusculus Ortega, Nagahama, Motta \& Bertani, 2013, and three new are species described here: Guyruita metallophila n. sp., Hapalopus serrapelada n. sp., and Idiops carajas n. sp. Five other "morphospecies" were represented by juveniles only: Ummidia sp. (Ctenizidae), Paratropis sp. (Paratropididae), Bolostromus sp. (Cyrtaucheniidae), Diplura sp. (Dipluridae), and Idiophtalma sp. (Barychelidae). The high number of juveniles suggests two alternatives: some species could be using the hypogean environment as reproductive shelter; the hypogean environment is used as a refuge by immatures. Two species appear to be troglophiles: G. metallophila and H. aymara.

http://zoobank.org/urn:1sid:zoobank.org:pub:C92F29CB-4B9C-402D-8AA6F8251DE49529.
\end{abstract}

Keywords: arachnids; canga; caves; conservation; taxonomy

\section{Introduction}

Spiders are among the most diverse and abundant arthropod groups in the hypogean environment (Reddell 2012), with troglobitic species (obligate cave-dwelling animals) known for more than 40 families around the world (Mammola and Isaia 2017). According to Trajano and Bichuette (2009), of the 54 Neotropical spider families, 33 have been recorded in caves in Brazil, with several troglomorphic species.

The hypogean environment, which includes caves and other aphotic environments, such as shallow subterranean habitats (Juberthie 2000; Pipan and Culver 2012), plays an important role as a selective filter to organisms from epigean habitats (Poulson and White

*Corresponding author. Email: rafaelbioferreira@gmail.com 
1969). Only those with adaptive features to the hypogean environment, such as nocturnal habits, generalist diet and well-developed sensorial organs other than vision (Howarth 1983), are able to colonize these habitats (Barr and Holsinger 1985; Trajano 2012).

The Infraorder Mygalomorphae comprises approximately 6\% of the Order Araneae, with currently more than 2800 species (World Spider Catalog 2017) in 16 families. Fourteen of these families have Neotropical representatives. Although Mygalomorph spiders are mainly nocturnal with sedentary habits (e.g. Gertsch 1982; Goloboff 1993; Hedin and Bond 2006), very few species were found in caves and usually represented in collections by few individuals or small populations (Trajano and Moreira 1991; Bernardi et al. 2007), mainly at the cave entrance (Ribera 2004; Pedroso and Baptista 2014), and are considered, in general, as incidental cave dwellers (Trajano and Bichuette 2009). Nevertheless, Guadanucci et al. (2014) recently reported a large cave-dwelling population, with more than 100 spiders of Trechona diamantina Guadanucci, Fonseca-Ferreira, Baptista \& Pedroso, 2016 (family Dipluridae).

More than 20 species of troglobitic mygalomorphs have been described from around the world (e.g. Gertsch 1982; Bertani et al. 2013; Maroquín 2014; Mammola and Isaia 2017). The troglomorphic features include depigmentation, eye loss or reduction, and long appendages (Gibert and Deharveng 2002; Christiansen 2012). In Brazil, three mygalomorph species have been described showing troglomorphic traits: the troglobitic Tmesiphantes hypogeus Bertani, Bichuette \& Pedroso, 2013, the putative troglobitic Harmonicon cerberus Pedroso \& Baptista, 2014, and possibly Masteria emboaba Pedroso, Baptista \& Bertani, 2015.

Research into the cavernicolous fauna of Brazil has been mainly associated with limestone caves (e.g. Pinto-Da-Rocha 1995; Trajano and Bichuette 2009; Trajano et al. 2016). The Amazonian cavernicolous fauna is poorly known and the only two records of mygalomorphs are from a population of an unidentified troglophilic barychelid, from Altamira-Itaituba, in the state of Pará (Trajano and Moreira 1991) and from the recently described troglomorphic H. cerberus (Pedroso and Baptista 2014). We present herein, the taxonomic synopsis of the mygalomorph spiders collected in caves from two distinct localities in the state of Pará, Brazil, located in southeastern Amazonia, as well as the descriptions of the new species found.

\section{Material and methods}

\section{Study area}

The caves sampled occur in iron formations located in southeastern state of Pará, known as Carajás region (eastern portion of the Brazilian Amazon rainforest) (Figure 1). Of the 242 caves sampled, 146 are in the city of Parauapebas (Serra Norte) inside the National Forest of Carajás (FLONA - Floresta Nacional de Carajás), which has approximately 411,000 ha and includes the cities of Parauapebas, Canaã dos Carajás and Água Azul do Norte. In the same region, there is a mosaic of protected areas forming a continuous area of 1.31 million hectares of preserved forest (Rolim et al. 2006). This whole area comprises mainly forest formations (ombrophilous or seasonal), and only 5\% of "campo rupestre" (rocky fields), which develops on the laterite hardpans (crusts) of high areas in the region (Campos and Castilho 2012).

The other 96 caves are located in the municipality of Curionópolis (Serra Leste), approximately $40 \mathrm{~km}$ from Parauapebas. In that area, the natural landscape has been almost completely replaced by land used for grazing, and the only forest fragments remaining are 


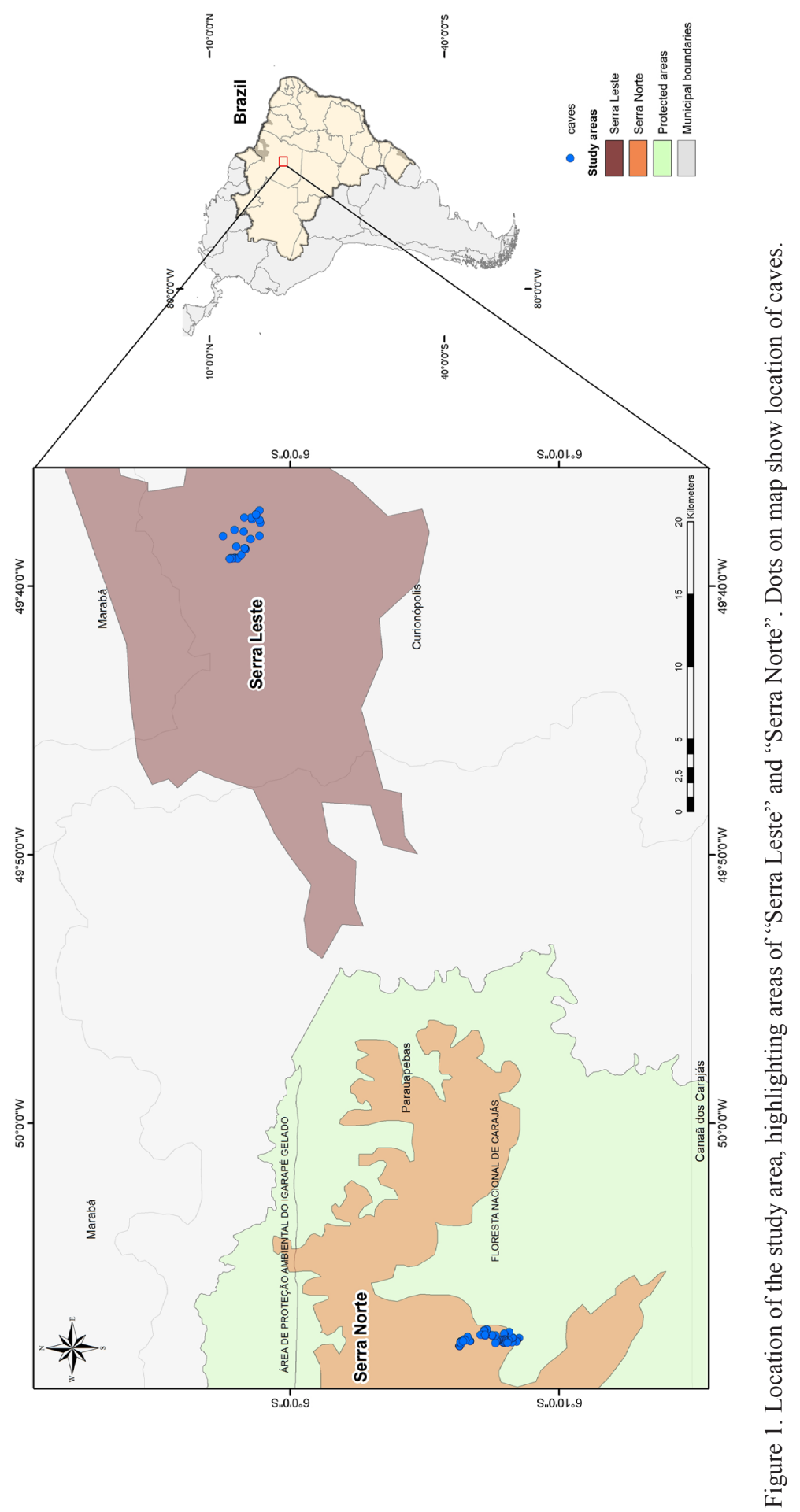


riparian forest and "campos rupestres" on hill tops. In general, the iron caves known in the region are located between 600 and $800 \mathrm{~m}$ of altitude and distributed among forested areas and "campos rupestres".

\section{Environmental and trophic description of the caves}

In general, caves in iron ore and "canga" have small dimensions, usually less than $30 \mathrm{~m}$ of linear development. "Canga" are geological formations composed mainly of itabirite and hematites (Simmons 1963) occurring in disconnected spots, standing as rocky outcrops of iron, and working as "iron islands" (Dorr 1964) of high altitudes (above $1000 \mathrm{~m}$ asl). "Canga" usually presents ecological features distinct from those of contiguous landscapes (Jacobi and Carmo 2008), namely irony rocky fields (Carmo and Jacobi 2013; Skirycz et al. 2014). Most caves in the region were formed in superficial depths, in contact with shallow soil or inserted directly in the surfaced "canga", where it is possible to find developed root systems inside them. These caves may also be subject to high temperatures due to the influence of epigeal environment, and moderate humidity (cases of saturated atmosphere or low humidity are rares in iron caves). In general, they do not contain active drip spots during the dry season. This condition completely changes during the wet season, since the superficiality of the cavities favors the penetration of rainwater, forming several drips, percolation and impoundment spots. Most caves only present areas of direct incidence of light and areas of penumbra, whereas aphotic areas are rare.

\section{Collecting methods}

Field collections took place between June 2010 and May 2011. Each cave was sampled twice, during the dry season (from May to October) and during wet season (from November to April) (Moraes et al. 2005). Collecting was done by active search and spiders were manually collected. Microhabitats, such as organic matter deposits, under rocks, very small accessible fissures, ceilings and walls, roots and areas with soil accumulation along with the substrate have been prioritized due to the fact that those places are more conducive to finding cave specimens. The specimens were collected with the help of tweezers and brushes and fixed in $70 \%$ ethanol.

\section{Taxonomic descriptions}

All specimens examined were deposited at IBSP - Instituto Butantan, São Paulo, Brazil (A. D. Brescovit). All measurements are in $\mathrm{mm}$ and were taken with an ocular lens. The length of legs segments was measured between the joints in dorsal view. The length and width of carapace, eye tubercle, labium, and sternum are the maximum values obtained. The total body length includes the chelicera and opisthosoma but not the spinnerets. The number and disposition of spines follows the terminology of Petrunkevitch (1925). Illustrations were made on a camera lucida attached to a stereomicroscope (Leica M80) and pictures were taken with a digital camera (DFC 295) attached to a trinocular stereomicroscope (Leica M80). The spermathecae were cleared with clove oil and illustrated in dorsal view. Palpal bulbs were removed from the cymbium and illustrated in prolateral, retrolateral and ventral views. Setae of the male tibia I were removed in order to illustrate the tibial spur better. 


\section{Results}

The whole survey yielded 254 specimens of mygalomorphs, 223 (87.8\%) of which are juveniles. In Parauapebas (Serra Norte - FLONA Carajás), mygalomorph spiders were collected in 69 (47\%) of the 146 caves sampled. In Curionópolis (Serra Leste), mygalomorph spiders were collected in $29(30 \%)$ of the 96 caves sampled. We registered 14 species of Mygalomorphae spiders belonging to seven families: Barychelidae (1 sp.), Ctenizidae (1 sp.), Cyrtaucheniidae (2 spp.), Dipluridae (1 sp.), Idiopidae (1 sp.), Paratropididae (1 sp.), and Theraphosidae (7 spp.). Theraphosidae was the most diverse group, with seven species, followed by Cyrtaucheniidae, with two species. The remaining families were represented by single species.

Of the 14 species recorded, nine were represented by adults: Dolichothele tucuruiense (Guadanucci, 2007), Hapalopus aymara Perdomo, Panzera and Pérez-Miles, 2009, Acanthoscurria geniculata (CL Koch, 1841), Theraphosa blondi (Latreille, 1804), Nhandu coloratovillosus (Schmidt, 1998), Fufius minusculus (Ortega, Nagahama, Motta and Bertani, 2013), plus three new species are described here, i.e. Guyruita metallophila n. sp., Hapalopus serrapelada n. sp., and Idiops carajas n. sp. Five other "morphospecies" were represented by juveniles only: Ummidia sp. (Ctenizidae), Paratropis sp. (Paratropididae), Bolostromus sp. (Cyrtaucheniidae), Diplura sp. (Dipluridae), and Idiophtalma sp. (Barychelidae).

Family Theraphosidae Thorell, 1869

Genus Guyruita Guadanucci, Lucas, Indicatti \& Yamamoto, 2007

Guyruita Guadanucci, Lucas, Indicatti and Yamamoto 2007: 992. Type species Guyruita cerrado Guadanucci, Lucas, Indicatti \& Yamamoto, 2007, by original designation.

\section{Guyruita metallophila n. sp.}

(Figures 2-12, 39)

Types

Holotype. Brazil, Pará: Curionópolis (Serra Leste), cave SL-60, 1 male, 10 June 2010, R. A. Zampaulo leg. (IBSP166635). Paratypes: 1 female, same data as holotype (IBSP166636); Pará: Curionópolis (Serra Leste), cave SL-01, 1 male, 4 July 2010, R. A. Zampaulo leg. (IBSP166631); Pará: Parauapebas (Serra Norte - FLONA Carajás), cave GEM-1795, 1 female, 28 August 2010, R.A. Zampaulo leg. (IBSP166633); Pará: Parauapebas (Serra Norte - FLONA Carajás), cave GEM-1743, 1 female, 11 March 2011, R.A. Zampaulo leg. (IBSP166630).

\section{Additional material examined}

Brazil, Pará: Curionópolis (Serra Leste), cave SL-60, 3 females, 10 June 2010, R.A. Zampaulo leg. (IBSP166634); same data as the previous, 1 female (IBSP166644); Curionópolis (Serra Leste), cave SL-58, 1 female, 27 June 2010, R.A. Zampaulo leg. (IBSP166637); 1 female (IBSP166629); Parauapebas (Serra Norte - FLONA Carajás), cave GEM-1760, 1 female, 24 November 2010, R.A. Zampaulo leg. (IBSP166628); Parauapebas (Serra Norte - FLONA Carajás), cave GEM-1740, 1 female, 23 September 2010, R.A. Zampaulo leg. (IBSP166632).

Diagnosis

Both males and females are distinguished from the other species, and resemble those of Guyruita cerrado, by the presence of dark transverse chevrons on the abdominal dorsum. 

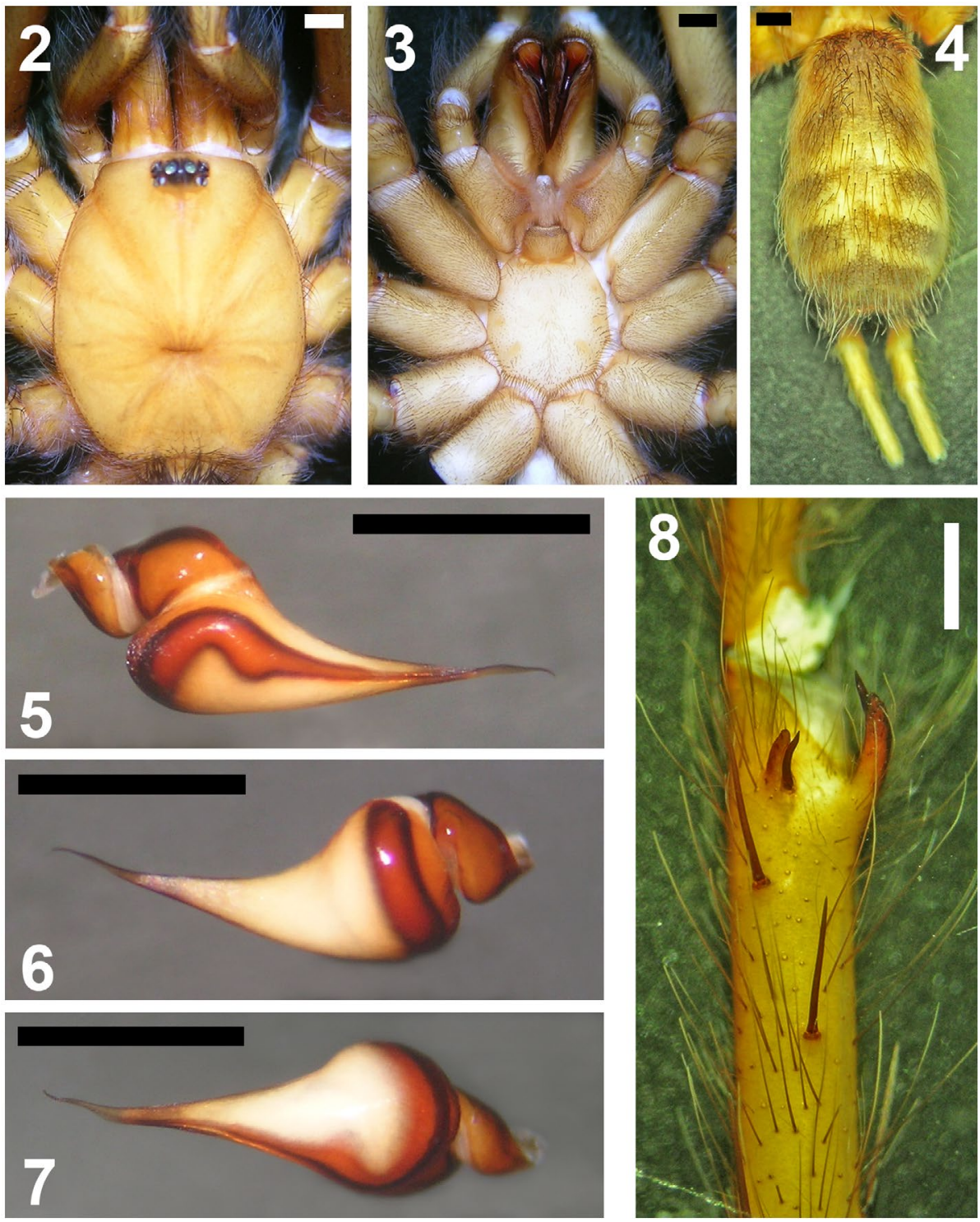

Figures 2-8. Guyruita metallophila n. sp., male holotype. 2. Prosoma, dorsal view. 3. Prosoma, ventral view. 4. Opisthosoma, dorsal view. 5. Palpal bulb, prolateral view. 6. Palpal bulb, retrolateral view. 7. Palpal bulb, ventral view. 8 . Tibial apophysis, prolateral-ventral view. Scales $=1 \mathrm{~mm}$.

Male specimens are distinguished from those of G. cerrado by the morphology of the embolus, which presents a conspicuous thin membrane at the apical end (Figures 5-7), and by the flexion of metatarsi I, which bends retrolaterally to the tibial apophysis, while in G. cerrado, metatarsi I bends between the two branches of tibial apophysis. Females are distinguished from those of G. cerrado by the morphology of the spermathecae (Figure 12), composed of two receptacles, with a single apical lobe, and extra lobes at the ventral face of receptacula, while females of G. cerrado present only lobes on the apical edge of each receptaculum. 

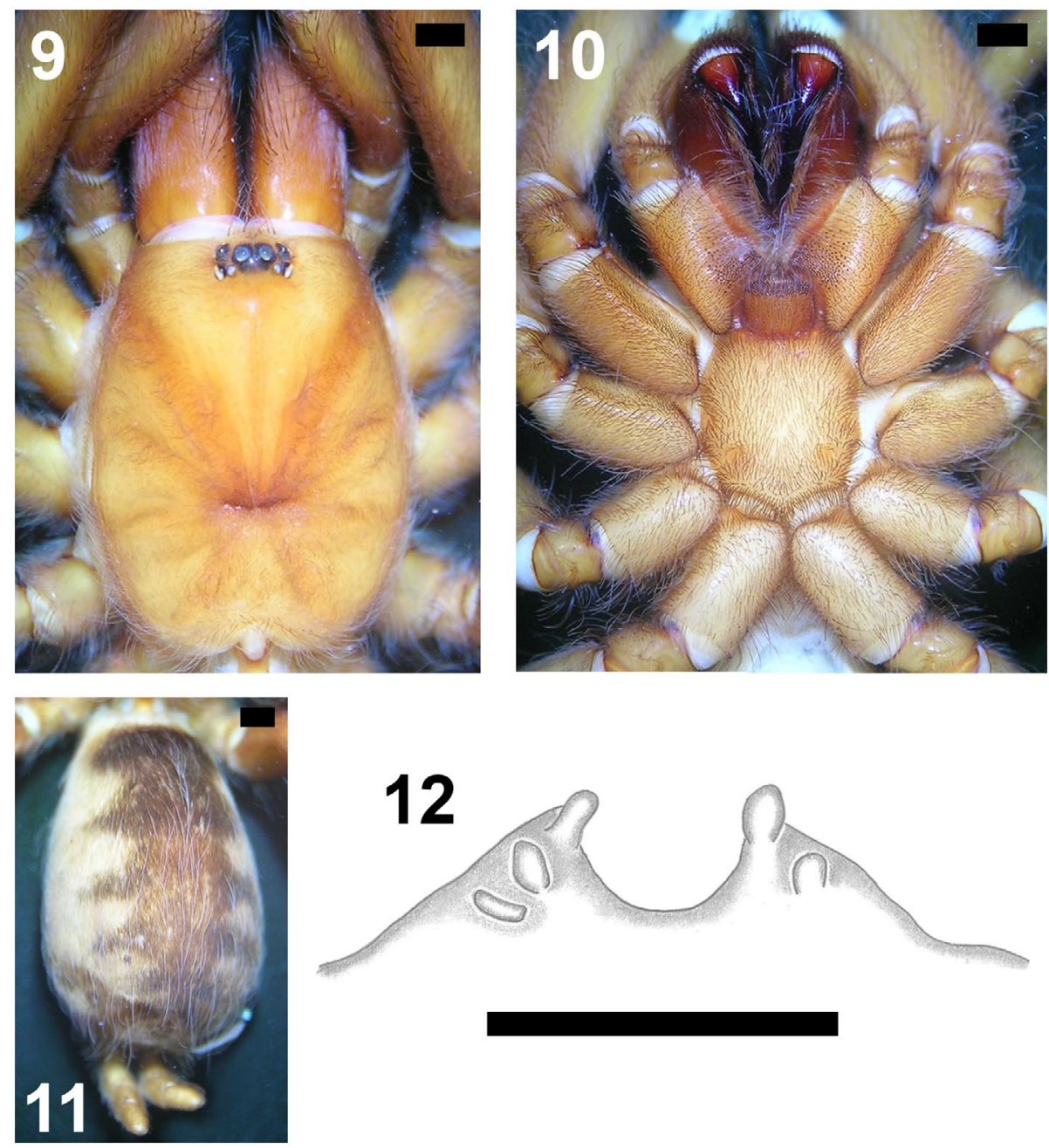

Figures 9-12. Guyruita metallophila n. sp., female paratype. 9. Prosoma, dorsal view. 10. Prosoma, ventral view. 11. Opisthosoma, dorsal view. 12. Spermathecae, dorsal view. Scales $=1 \mathrm{~mm}$.

\section{Description}

Male (holotype). Total length: 23.7. Carapace: length 9.7, width 9. Eye tubercle: length 0.5, width 1.6. Labium: length 1.1, width 1.6. Sternum: length 5.5, width 4. Cheliceral basal segment with 10 teeth each. Labium quadrate bearing around 150 cuspules. Maxilla with more than 100 cuspules. Sternum oval, posterior sigilla more than one diameter from margin (Figure 3). Fovea straight (Figure 2). Measurements: Palp: femur 5.5/ patella 2.6/ tibia 4.4/ cymbium 2/ total 14.5. Legs I: femur 11/ patella 5.4/ tibia 9.2/ metatarsus $9.5 /$ tarsus 7/ total 42.1; II: 8/ 4.9/ 7.2/ 8.7/ 8/ 36.8; III: 9.7/ 4.4/ 7.2/ 7.7/ 5.2/34.2; IV: 11.2/ 4.1/ 9.5/ 12.4/ 6.2/ 43.4. Spines: tarsi without spines. Palp: femur (d) p1, tibia (p) 1, tibia (p) 1-1. Legs I: femur (d) 3, tibia (p) 1-1, (v) 1-2-1, metatarsus (v) 1-1, (p) 1; II: femur (d) 3, tibia (p) 2, (v) 1-1-ap3, metatarsus (v) 1-ap2, (p) 1; III: femur (d) p1-2-r1-2, patella (p) 1; tibia (v) 1-2-ap2, (p) 1-1, (r) 1-1, metatarsus (r) 1-1, (v) 1-2-ap3, (p) 1-1-1; IV: femur (d) r1, tibia (r) 1-1, (v) 2-2-ap3, metatarsus (r) 1-1, (v) 1-1-ap3, (p) 1-1. Palpal bulb long and tapering, 
with a thin membrane-like keel on the prolateral face of the embolus (Figures 5-7). Tibial apophysis with two branches, retrolateral, the largest, bearing an apical spine, prolateral short, adjacent spine of the same size (Figure 8). Metatarsus bends retrolaterally to the tibial apophysis. Extension of scopula on ventral face of metatarsus: I-IV whole article, denser at the apical portion. Scopula on tarsi: I-II entire, III-IV divided. Superior tarsal claws without teeth, clavate trichobotria in two parallel rows. Eyes: anterior row slightly procurved, posterior slightly recurved. Carapace (Figure 2) and legs pale brown. Abdomen with dark transversal chevrons (Figure 4).

Female (paratype IBSP166633). Total length: 23. Carapace: length 9.5, width 6.7. Eye tubercle: length 0.9 , width 1.8. Labium: length 1.2, width 1.7. Sternum: length 4.1, width 3.7. Cheliceral basal segment with 11 teeth each. Labium quadrate more than 150 cuspules. Maxilla with more than 100 cuspules. Sternum oval, posterior sigilla more than one diameter from margin (Figure 10).Fovea straight (Figure 9). Measurements: Palp: femur 4.6/ patella 2.9 / tibia $4.4 /$ tarsus 2.8 / total 14.7 . Legs I: femur $8.7 /$ patella 5.6/ tibia 6.9/ metatarsus 5.2/ tarsus 3.5/ total 29.9; II: 6.7/ 4.5/ 5.1/ 3.8/ 3.5/ 23.6; III: 4.6/ 3.2/ 3.1/ 3.8/ 2.6/ 17.3; IV: 8.4/ 4.2/ 7.2/ 6.5/ 3.6/ 29.9. Spines: tarsi without spines. Palp: femur (d) p1, tibia (v) ap3. Legs I: femur (d) p1, tibia (v) ap2, metatarsus (v) ap1; II: femur (d) p1, tibia (v) ap2, metatarsus (v) 2; III: patella (p)1; tibia (v) ap3, (p) 1, (r) 1, metatarsus (r) 1-1, (v) 1-ap3, (p) 1-1-1; IV: tibia (r) 1-1, (v) ap2, metatarsus (r) 1, (v) 1-ap3, (p) 1. Spermathecae formed by two receptacles, each with an apical single lobe, and lobes (two lobes on the left receptaculum and one on the right receptaculum) on the ventral surface (Figure 12). Scopula on ventral metatarsi: I-IV more than half occupied, on tarsi IV the scopula is less dense. Scopula on tarsi: I-II entire with a sparse line of setae, III-IV divided by a band of thick setae. Superior tarsal claws without teeth, clavate trichobotria in two parallel rows. Eyes disposition and coloration as in male (Figures 9-11).

Etymology

The species epithet refers to the typical vegetation associated with ironstone deposits, considering that these spiders were the most common in the area sampled.

Genus Dolichothele Mello-Leitão, 1923

Dolichothele Mello-Leitão 1923: 119. Type-species Dolichothele exilis Mello-Leitão, 1923 , by original designation.

Dolichothele tucuruiense (Guadanucci, 2007)

(Figure 40)

Oligoxystre tucuruiense Guadanucci 2007: 15, figs 30-33.

Dolichothele tucuruiense: Lucas and Indicatti 2015: 4.

Material examined

Brazil, Pará: Parauapebas (Serra Norte - FLONA Carajás), cave GEM-1790, 1 female, 21 August 2010, R.A. Zampaulo leg. (IBSP166624); Parauapebas (Serra Norte - FLONA Carajás), cave GEM-1712, 1 juvenile female, 30 October 2010, R.A. Zampaulo leg. (IBSP166625).

\section{Remarks}

Dolichothele tucuruiense was only known from its type locality (Tucuruí, state of Pará, Brazil). The specimens included herein, comprise the second record from the Amazonian forest, which extends the geographical distribution $250 \mathrm{~km}$ to the south. 
Genus Hapalopus Ausserer, 1875

Hapalopus Ausserer 1875: 175; pl. 6, figs 17-18. Type species Hapalopus formosus Ausserer, 1875 , by monotypy.

\section{Hapalopus serrapelada n. sp.}

(Figures 13-25)

\section{Types}

Holotype. Brazil, Pará: Curionópolis (Serra Leste), cave SL-06, 1 male, 28 June 2010, R.A. Zampaulo leg. (IBSP166623). Paratypes: Pará: Curionópolis (Serra Leste), cave SL-97, 1 female, 28 July 2010, R.A. Zampaulo leg. (IBSP166622); Pará: Parauapebas (Serra Norte - FLONA Carajás), cave GEM-1712, 1 female, 30 October 2010, R.A. Zampaulo leg. (IBSP166621).

\section{Diagnosis}

Both males and females can be diagnosed by the presence of three longitudinal dark stripes on the abdomen dorsum, middle stripe thicker than the marginal ones (Figures 13, 23). Male representatives are distinguished from congeners by the palpal bulb with an inferior prolateral keel split in two parts, a conspicuous retrolateral keel, and a serrated subapical keel (Figures 18-20). Females can be distinguished from congeners by the unique shape of spermathecae composed of two receptacula inserted in a single base, each receptaculum with strongly concave apical portion (Figures 24-25).
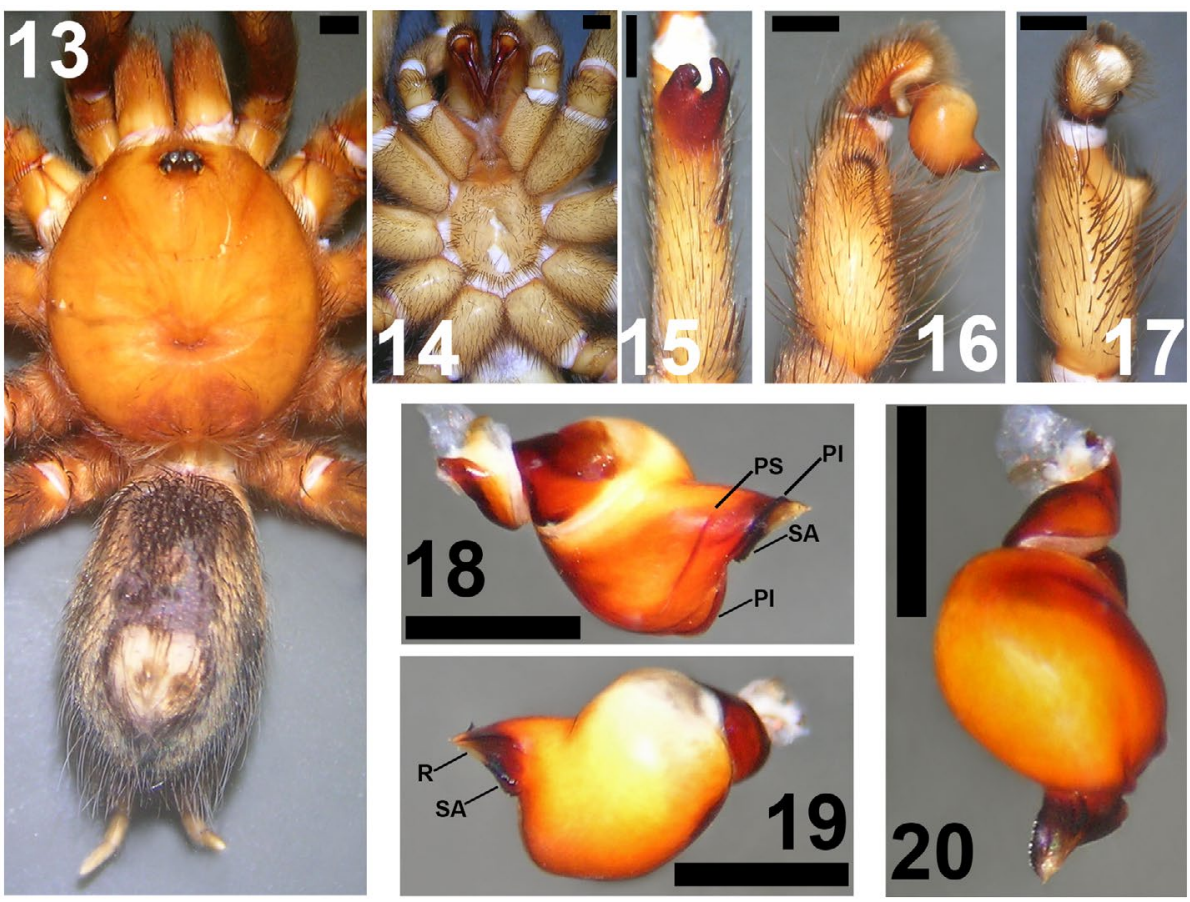

Figures 13-20. Hapalopus serrapelada n. sp., male holotype 13. Prosoma and opisthosoma, dorsal view. 14. Prosoma, ventral view. 15. Tibial apophysis, ventral view. 16. Palpal tibia and cymbium, retrolateral view. 17. Palpal tibia and cymbium, ventral view. 18. Palpal bulb, prolateral view. 19. Palpal bulb, retrolateral view. 20. Palpal bulb, ventral view. $\mathrm{PS}=$ prolateral superior keel; $\mathrm{PI}=$ prolateral inferior keel; $\mathrm{R}=$ retrolateral keel; $\mathrm{SA}=$ subapical keel. Scales $=1 \mathrm{~mm}$. 

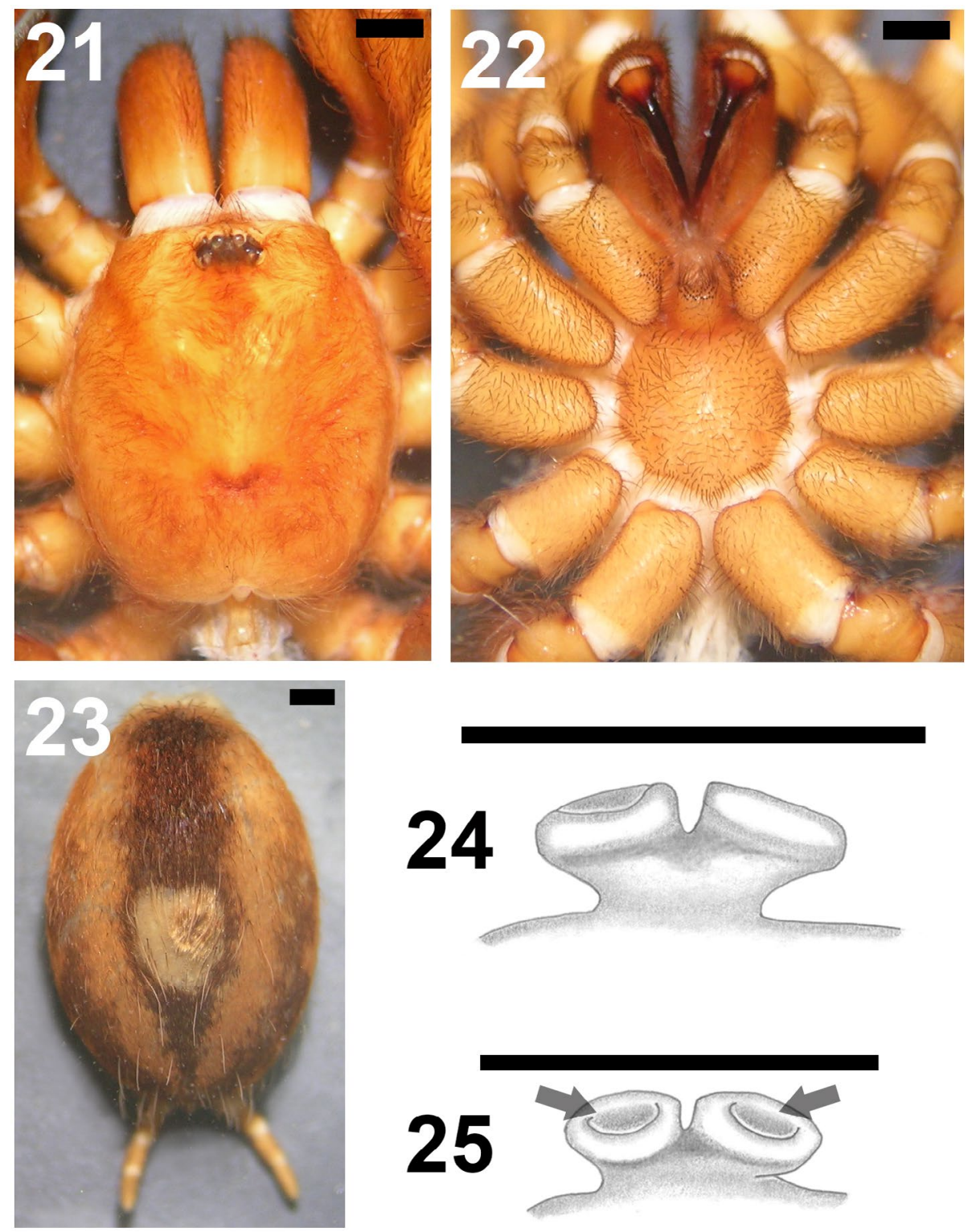

Figures 21-25. Hapalopus serrapelada n. sp., female paratype. 21. Prosoma, dorsal view. 22. Prosoma, ventral view. 23. Opisthosoma, dorsal view. 24. Spermathecae, dorsal view. 25. Spermathecae, anterior face, arrows pointing the concavity on each receptaculum. Scales $=1 \mathrm{~mm}$.

\section{Description}

Male (holotype). Total length: 22.7. Carapace: length 11.37, width 8.6. Eye tubercle: length 0.7, width 1.2. Labium: length 0.9, width 1.2. Sternum: length 4.7, width 3.7. Cheliceral basal segment with 10-11 teeth in a single row. Labium slightly wider than long bearing 15 cuspules. Maxilla with approximately 80 cuspules (Figure 14). Sternum oval, posterior sigillae, approximately one diameter from margin. Fovea short and procurved (Figure 13). Measurements: Palp: femur 4.2/ patella 2.4/ tibia 3.7/ cymbium 1.2/ total 11.5. Legs I: 
femur 8/ patella 4.6/ tibia 6.4/ metatarsus 5.2/ tarsus 3.4/ total 27.6; II: 7/ 3.7/ 5.2/ 5.2/ 3.5/ 24.6; III: 5.9/ 3.4/ 4.5/ 7.2/ 3.7/ 24.7; IV: 8.6/ 3.6/ 7/ 10.2/ 4.9/34.3. Spines: tarsi without spines. Palp: femur (d) p1, patella (p) 1. Legs I: femur (d) p1, patella (p) 1, tibia (p) 1, (v) 2-1-1-ap1, metatarsus (v) ap1, (p) 1-1, (r) 1; II: femur (d) p1, tibia (p) 1, (v) 2-2-ap3, metatarsus (v) 3-1-1-ap2, (p) 1-1-1; III: femur (d) p1, patella (p)1; tibia (v) 4-2-ap3, (p) 1-1, (r) 1-1, metatarsus (r) 1-1-1, (v) 2-2-1-1-ap3, (p) 1-1-1; IV: femur (d) 2, patella (p) 2, (r) 1, tibia (r) 1-1-1, (v) 2-4-1-ap3, (p) 1, metatarsus (r) 1-1-1, (v) 3-2-2-1-1-ap3, (p) 1-11. Palpal bulb with short embolus, superior and inferior prolateral keels present, inferior split in two, retrolateral keel also present, subapical keel serrated (Figures 18-20). Palpal tibia with conspicuous retrolateral process, bearing short and thick setae (Figures 16-17). Tibial apophysis composed of two converging branches, prolateral short and thick, retrolateral long and thin (Figure 15). Metatarsus touches both branches of tibial apophysis when flexed. Extension of scopula on ventral face of metatarsus: I-IV apical portion. Scopula on tarsi: I-II entire, with sparse thick setae, III-IV divided. Superior tarsal claws with two or three small teeth, clavate trichobotria in two parallel rows. Eyes: anterior row slightly procurved, posterior slightly recurved. Carapace pale brown, legs with dark covering setae. Abdomen with three dark longitudinal stripes, mid-stripe is the thickest (Figure 13), only type III urticating hair is present in a central oval patch on the abdominal dorsum.

Female (Paratype IBSP 166621). Total length: 23.3. Carapace: length 11, width 6.3. Eye tubercle: length 0.6, width 1.1. Labium: length 0.9, width 0.7. Sternum: length 2.4, width 2.7. Cheliceral basal segment with 10 teeth each. Labium subquadrate with 29 cuspules. Maxilla with approximately, 70 cuspules (Figure 22). Sternum rounded, posterior sigilla one diameter from margin. Fovea short and procurved (Figure 21). Measurements: Palp: femur 2.6/ patella 2.4/ tibia 1.6/ tarsus 1.8/ total 8.4. Legs I: femur 4.1/ patella $2.4 /$ tibia $2.1 /$ metatarsus 1.6/ tarsus 1.6/ total 11.8; II: 2.8/ 2.2/ 1.7/ 1.9/ 1.7/ 10.3; III: 2.3/ 2.1/ 2.1/ $2.7 /$ 2.1/ 11.3; IV: 3.5/ 2.3/ 2.8/ 4.1/ 2.1/ 14.8. Spines: tarsi without spines. Palp: tibia (v) ap2. Legs I: femur (d) p1, metatarsus (v) ap1; II: femur (d) p1, metatarsus (v) 1-ap2; III: tibia (v) 1-ap2, metatarsus (r) 1, (v) 2-1-ap3, (p) 1-1; IV: tibia (r) 1, (v) 1-ap2, metatarsus (r) 1, (v) 1-1-2-ap3, (p) 1-1. Spermathecae formed by two semi-circular receptacles, each with an apical single lobe, concave at the apical portion (Figures 24-25). Scopula on ventral metatarsi: I-IV on apical portion, on tarsi IV the scopula is less dense. Scopula on tarsi: I-IV divided by a band of thick setae. Superior tarsal claws with two small teeth, clavate trichobotria in two parallel rows. Eyes disposition, coloration, and abdominal stripes and urticating hair as in male (Figures 21,23), except by the absence of dark covering setae on the legs of female.

\section{Etymology}

The species epithet (Serra Pelada - English: bald mountain) is a noun in apposition referring to a region nearby the type locality. Serra Pelada was one of the world's largest gold mines, regarded as the beginning of mining activities in the region in the early 1980s.

Hapalopus aymara Perdomo, Panzera \& Pérez-Miles, 2009

(Figures 26-28)

Hapalopus aymara Perdomo et al. 2009: 53, figs 1-9.

\section{Material examined}

Brazil: Pará: Parauapebas (Serra Norte - FLONA Carajás), cave GEM-1179, 1 female, 26 February 2011, R.A. Zampaulo leg. (IBSP166642); Parauapebas (Serra Norte - FLONA Carajás), cave GEM-1690, 1 female, 17 March 2011, R.A. Zampaulo leg. (IBSP166641); Parauapebas (Serra Norte - FLONA Carajás), cave GEM-1750, 1 female, 16 March 

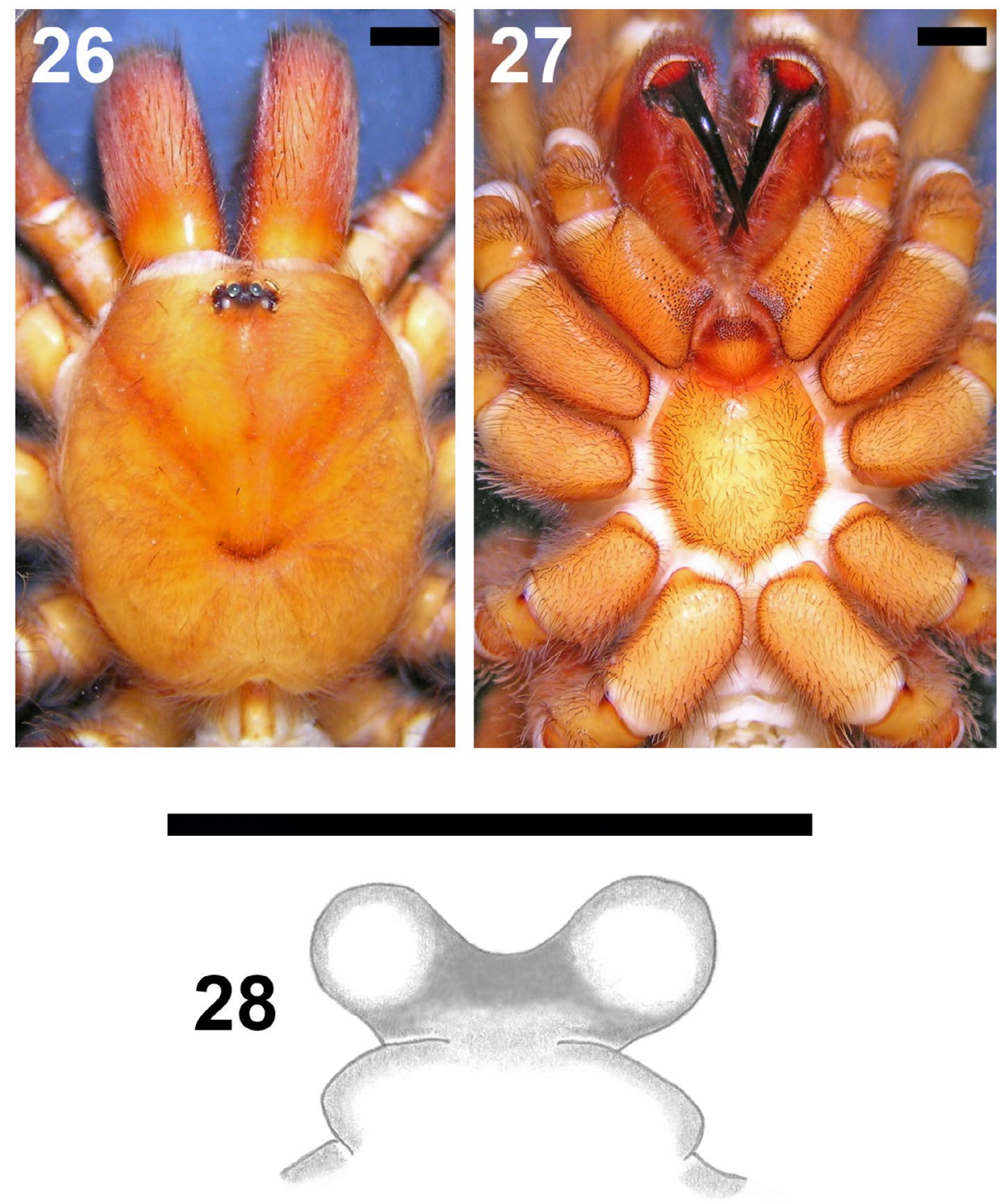

Figures 26-28. Hapalopus aymara, female. 26. Prosoma and opisthosoma, dorsal view. 27. Prosoma, ventral view. 28. Spermathecae, dorsal view. Scales $=1 \mathrm{~mm}$.

2011, R.A. Zampaulo leg. (IBSP166640); Parauapebas (Serra Norte - FLONA Carajás), cave GEM-1624, 1 female, 17 March 2011, R.A. Zampaulo leg. (IBSP166638); Curionópolis (Serra Leste), cave SL-52, 1 juvenile female, 3 June 2010, R.A. Zampaulo leg. (IBSP166643); Curionópolis (Serra Leste), cave SL-31, 1 female, 4 December 2010, R.A. Zampaulo leg. (IBSP166639).

\section{Remarks}

The specimens examined here, share the spermathecal morphology (Figure 28), aspect of labium, maxilae, and sternum (Figure 27) with the type specimens of $H$. aymara. However, 
the specimens examined here do not have the legs darker than the body, as in the original description. It is possible that the color pattern described has faded in ethanol. H. aymara is a species that occurs in the Southern part of Amazonian forest. Nevertheless, we cannot rule out the possibility of the specimens here represent an undescribed species. Until male representatives are collected in the same locality and compared with those of H. aymara, it is not possible to choose either hypothesis and, therefore, we prefer to consider it as belonging to $H$. aymara.

Genus Acanthoscurria Ausserer, 1871

Acanthoscurria Ausserer 1871: 205. Type species Mygale geniculata CL Koch, 1841, by original designation.

Acanthoscurria geniculata (CL Koch, 1841)

(Figure 41)

Mygale geniculata CL Koch 1841: 43, fig. 718.

Acanthoscurria geniculata: Ausserer 1871: 206, fig. 10; Simon 1892: 158; F.O.P.

Cambridge 1896: 737, pl. 34, fig. 17; Schiapelli and Gerschman de Pikelin 1979: 293, figs 15-16; Bertani 2001: 325, figs 45-47; Paula et al. 2014: 64, figs 1-13; World Spider Catalog 2015.

Acanthoscurria transamazonica Piza 1972: 99, fig. 1; Paula et al. 2014: 64; World Spider Catalog 2015.

Material examined

Brazil: Pará: Curionópolis (Serra Leste), cave SL-61, one male, 10 January 2011, R.A. Zampaulo leg. (ISLA 15190).

Remarks

This is the first record of $A$. geniculata for the Carajás region, although Paula et al. (2014) provided several distributional records from surrounding areas.

Genus Theraphosa Thorell, 1870

Theraphosa Thorell 1870: 161. Type species Mygale blondi Latreille, 1804, by original designation.

\section{Theraphosa blondi (Latreille, 1804)}

Mygale blondi Latreille 1804: 159; Latreille 1806: 83, pl. 5, fig. 1; Hahn 1802: 15, fig. 1; Koch 1842: 91, fig. 748.

Theraphosa blondi: Thorell 1870: 163; Simon 1903: 942, fig. 1086; Pérez-Miles et al. Bertani 1996: 59, figs 46-47; Bertani 2000: 30, fig. 363; Bertani 2001: 320, figs 14-15, $157-159$.

\section{Material examined}

Brazil: Pará: Curionópolis (Serra Leste), cave SL-36, one male, 31 January 2011, R.A. Zampaulo leg. (ISLA 15189).

Remarks

Spiders of T. blondi are very common in the Amazonian forest, with many records (Museu Paraense Emilio Goeldi scientific collection - MPEG), from the surrounding Carajás region. 
Genus Nhandu Lucas, 1981

Nhandu Lucas 1981: 157; Raven 1985: 156; Pérez-Miles, Lucas, Silva Jr and Bertani 1996: 53, fig. 30. Type species Nhandu carapoensis Lucas, 1981, by monotypy.

Nhandu coloratovillosus (Schmidt, 1998)

(Figure 42)

Brazilopelma coloratovillosus Schmidt 1998: 2, fig. 1; Schmidt and Samm 1998: 7-12, figs 1-3; Vol 1999: 11, fig. B.

Nhandu coloratovillosus: Bertani 2001: 314, figs 141-144, 192.

Material examined

BRAZIL: Pará: Curionópolis (Serra Leste), cave SL-73, one male, 07 January 2011, R.A. Zampaulo leg. (ISLA 15193).

Remarks

Bertani (2001) has previously recorded $N$. coloratovillosus from the Carajás region.

Family Cyrtaucheniidae Simon, 1889

Genus Fufius Simon, 1888

Fufius Simon 1888: 213. Type species Fufius atramentarius Simon, 1888, by monotypy,

Fufius minusculus Ortega, Nagahama, Motta \& Bertani, 2013

Fufius minusculus Ortega et al. 2013: 107, figs 27-36, 45.

Material examined

BRAZIL: Pará: Curionópolis (Serra Leste), SL-4, 1 female, 3 July 2010, R.A. Zampaulo leg. (IBSP166626).

Remarks

This is the first record of $F$. minusculus for the state of Pará, Carajás region, extending the distributional range more than $500 \mathrm{~km}$ to the northwest.

Family Idiopidae Simon, 1889

Genus Idiops Perty, 1833

Idiops Perty 1833: 197; O. P. Cambridge 1870: 101; Simon 1892: 89; Raven 1985: 139.

Type species Idiops fuscus Perty, 1833, by monotypy.

\section{Idiops carajas n. sp.}

(Figures 29-38)

Types

Holotype. Brazil, Pará: Parauapebas (Serra Norte - FLONA Carajás), cave GEM-1758, 1 male, 14 March 2011, R.A. Zampaulo leg. (IBSP166619). Paratype: Pará: Parauapebas (Serra Norte - FLONA Carajás), cave GEM-1743, 1 female, 23 September 2010, R.A. Zampaulo leg. (IBSP166620)

Additional material examined

Brazil, Pará: Almeirim: 1 male, 2004, T.C.S Ávila-Pires leg. (MPEG 7591); Pará: Jari, 1 male, 03 April 2005, T. Gardener leg. (MPEG 7539); Pará: Jari, 1 male, 17-23 August 

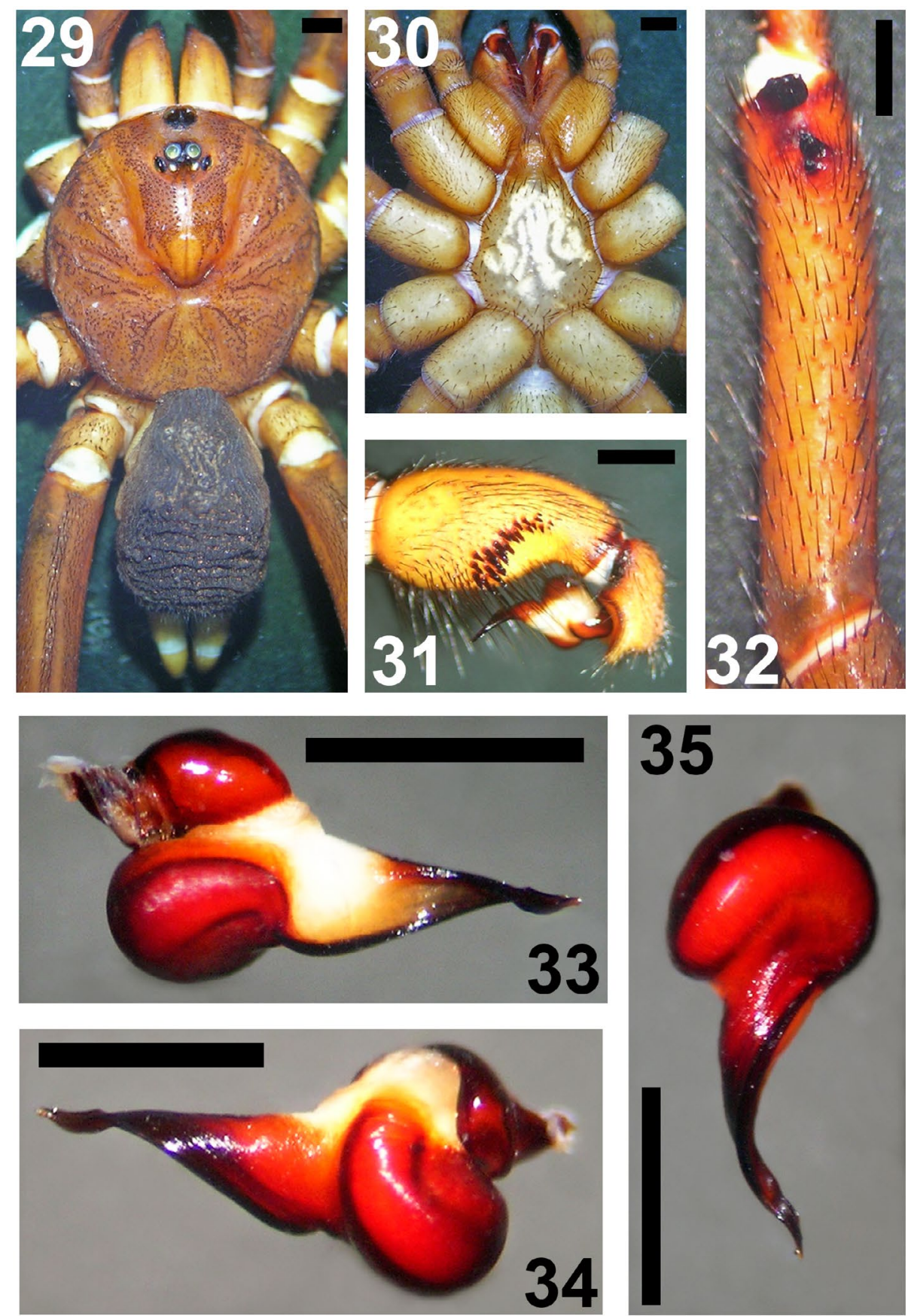

Figures 29-35. Idiops carajas n. sp., male holotype. 29. Prosoma and opisthosoma, dorsal view. 30. Prosoma, ventral view. 31. Palpal tibia and cymbium, retrolateral view. 32. Tibial apophysis, prolateral view. 33. Palpal bulb, prolateral view. 34. Palpal bulb, retrolateral view. 35. Palpal bulb, ventral view. Scales $=1 \mathrm{~mm}$. 

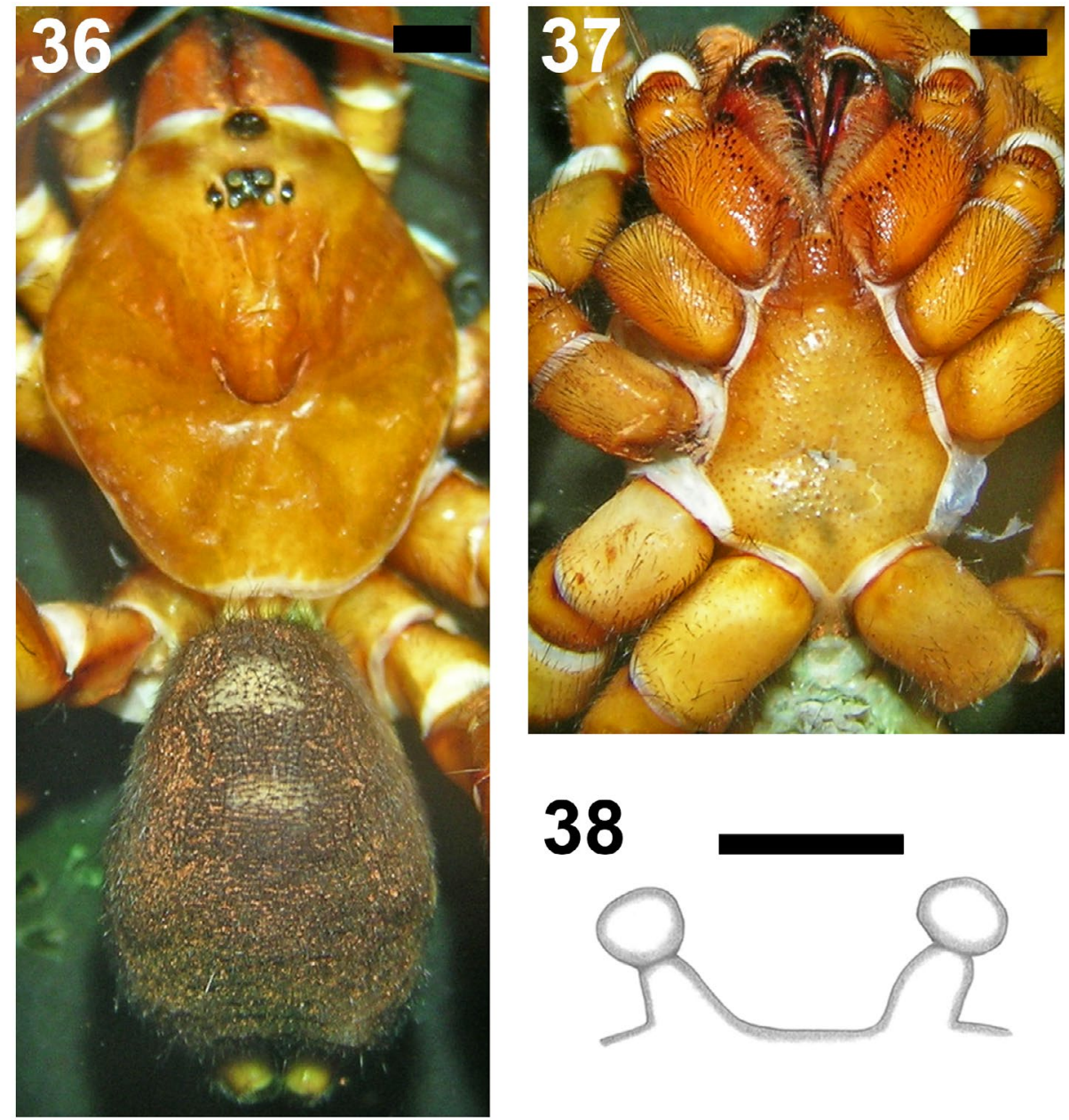

Figures 36-38. Idiops carajas n. sp., female paratype. 36. Prosoma and opisthosoma, dorsal view. 37. Prosoma, ventral view. 38. Spermathecae, dorsal view. Scales $=1 \mathrm{~mm}$.

2004, T. Gardener leg. (MPGE 7592); Pará: Jari, 2 males, 22 March 2005, T. Gardener and M.A. Ribeiro Júnior leg. (MPEG 7590); Pará: Jari, 1 male, 22 March 2005, T. Gardener and M.A. Ribeiro Júnior leg. (MPEG 7587).

\section{Diagnosis}

Males are distinguished from congeners by the long and straight embolus (in lateral view), bearing a keel in the apex (Figures 33-34). In dorsal view, the embolus has a curvature pointing prolaterally (Figure 35). Females are distinguished from congeners by the aspect of the spermathecae, composed of two receptacula far from each other, with a rounded termini and a conspicuous constriction below the termini (Figure 38). Yamamoto and Brescovit (2011) reported four species of Idiops from Amazonian region, all sharing the straight embolus in lateral view, leg I with several spines and metatarsi I with a slight curvature at its midlength. One of these species is considered herein as new (I. carajas) and the material examined by Yamamoto and Brescovit (2011) is included here, in additional material examined section. 

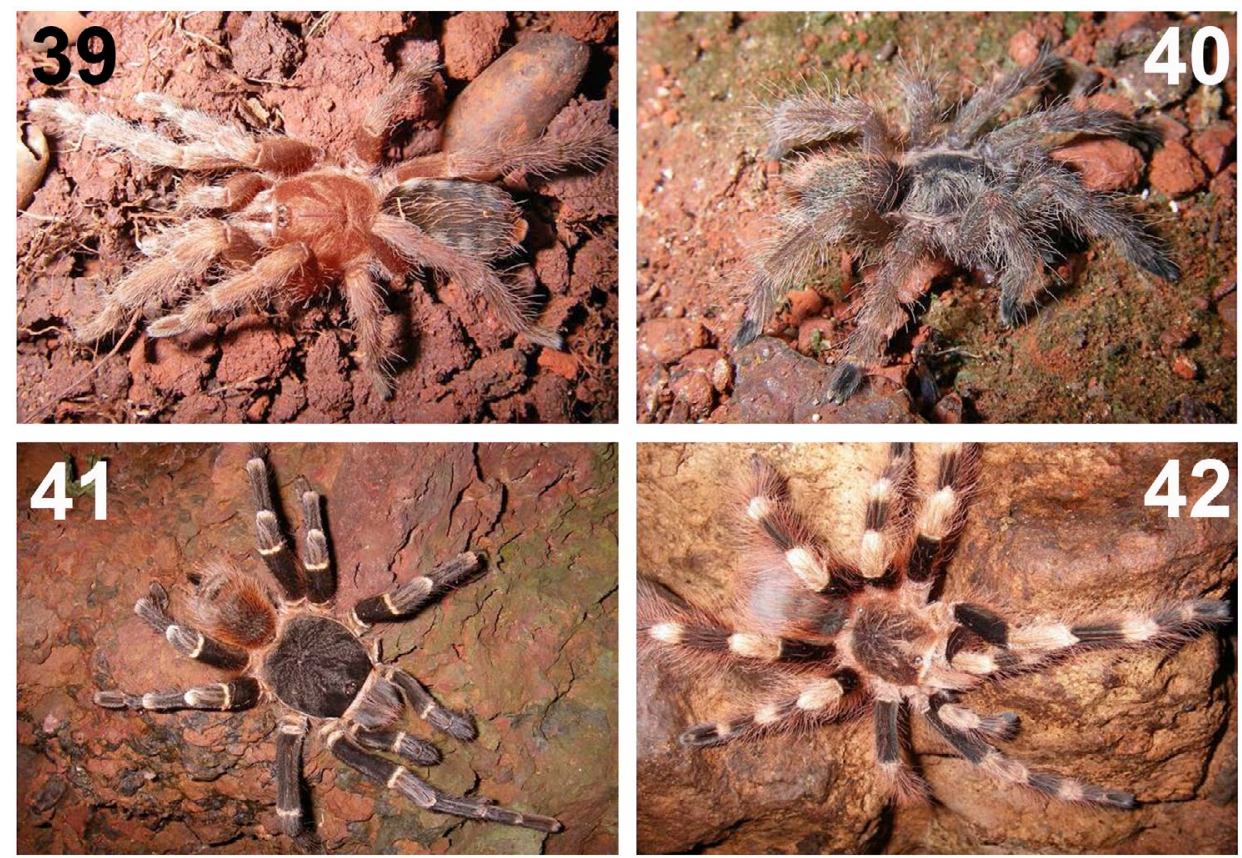

Figures 39-42. Dorsal habitus, live specimens of mygalomorphs.39. Guyruita metallophila n. sp., female. 40. Dolichothele tucuruiense, female. 41. Acanthoscurria geniculata, female. 42. Nhandu coloratovillosus, female.

\section{Description}

Male (holotype). Total length: 14.2. Carapace: length 7, width 7.2, carapace covered with several granules with short setae. Eye tubercle: length 0.8 width 1.4 , distance to anterior lateral eyes 0.5. Labium: length 1, width 1.2. Sternum: length 4.2, width 3.5, sternum not extending between coxae IV. Cheliceral basal segment strong teeth in a straight row, short row of small teeth on proximal half. Rastellum on apical portion of basal segment of chelicerae, composed of several short and thick spines on a tubercle. Labium trapezoid without cuspules. Maxilla without cuspules. Sternal anterior and median sigillae on margin, posterior not visible (Figure 30). Fovea procurved, discrete bulge anterior to thoracic fovea (Figure 29). Measurements: Palp: femur 4/ patella 2.1/ tibia 3.3/ cymbium 1.5/ total 10.9. Legs I: femur 6.5/ patella 3.4/ tibia 5.1/ metatarsus 4.6/ tarsus 2/ total 21.6; II: 6.1/ 3/ 4.7/ 4.1/ 1.7/ 19.6; III: 5.1/ 2.9/3.3/4.1/ 2.5/ 17.9; IV: 6.2/3.7/ 5.8/ 5.7/ 3.2/ 24.6. Spines. Palp: femur (d) 1-1, tibia (r) 24, cymbium (d) 7. Legs I: femur (d) 1-1, tibia (v) 2-1-2-2-2-2-1, metatarsus (p) 2-1-2-1, (r) 1-1-1-3-2-2-1-1-2-2, tarsus (p) 1-1-1-1-1-1-1-1, (r) 1-2-2-1-21-2; II: femur (d) 1-1, tibia (v) 1-1-1-1-1-1, metatarsus (p) 1-1-1-1-1-1-1-1, (r) 1-1-1-1-11-1-1-1-1; tarsus (p) 1-2-2-2-1-2-1, (r) 2-2-2-2-1-1-2; III: tibia (v) ap2, (p) 1-1-1-1-1-1-1, (r) 1, metatarsus (v) 1-1-3-ap4, (r) 1-1-1, (p) 1-1-1-1-1-1; IV: femur (d) 1-1; patella (p) 11; tibia (v) 1-1-1-ap3, metatarsus (v) 1-1-1-ap3; tarsus (p) 1-1-1-1-1-1-1-1-1-3-2-3, (r) 1-1. Superior tarsal claws with teeth on all legs, inferior tarsal claw on all legs. Scopula on all tarsi, denser on tarsi II-IV. Metatarsal scopula absent. Male tibial apophysis on leg I composed of two branches, apical branch larger than subapical (Figure 32). Palpal bulb piriform, embolus flat with subapical torsion (Figures 33-35). Palpal tibiae strongly swol- 
len, with retrolateral depression (Figure 31). Apical segment of posterior lateral spinnerets very short, basal segment the longest. Carapace, palp, and legs uniform brown, abdomen darker then carapace, without markings or color patterns (Figure 29).

Female (paratype). Total length: 28.1. Carapace: length 12.2, width 11. Eye tubercle: length 0.9 width 2 , distance to anterior lateral eyes 1 . Labium: length 2.8, width 1.3. Sternum: length 10, width 6.5, sternum not extending between coxae IV. Cheliceral basal segment with strong teeth in a straight row, short row of small teeth on proximal half. Rastellum on apical portion of basal segment of chelicerae, composed of several short and thick spines on a tubercle. Labium trapezoid with two cuspules. Maxilla with more than 30 cuspules on prolateral portion of ventral face. Sternal anterior and median sigillae on margin, posterior not visible (Figure 37). Fovea procurved, discrete bulge anterior to thoracic fovea (Figure 36). Measurements: Palp: femur 5.7/ patella 2.7/ tibia 4/ tarsus 4/ total 16.4. Legs I: femur 6.8/ patella 5.1/ tibia 4.9/ metatarsus 3.6/ tarsus $1.7 /$ total 22.1; II: 6.5/ 4.4/ 4.2/ 3.2/ 2.2/ 20.5; III: 6.6/ 4.5/ 3.7/ 4.2/ 3/ 22; IV: 7.7/ 5.7/ 6.2/ 6.4/ 4/ 30. Spines. Palp: tibia (r) 42, (p) 39, tarsus (p) 40, (r) 40, (v) ap4. Legs I: tibia (p) 30, (r) 42, metatarsus (r) 38, (p) 52, tarsus (p) 14, (r) 14, (v) ap5; II: tibia (p) 20, (r) 3, (v) 2, metatarsus (r) 14, (p) 34; tarsus (p) 18, (r) 10, (v) ap7; III: patella (p) 1-1-1-1-2-2-2-4; tibia (p) 1-1-1-1-3, (r) 2-1-1-1; metatarsus (p) 12, (r) 1-2-2-ap1; tarsus (r) 1-1-1-1, (p) 2-1-2-1-ap1, (v) 1-1-1-1 IV: patella (p) 28; metatarsus (v) 1-1-2-2-ap3, tarsus (v) 20. Spermatheca composed of two receptacles, longer than wide, with a single termini (Figure 38). Superior tarsal claws with teeth on all legs, inferior tarsal claw on all legs. Scopula absent on tarsi and metatarsi. Apical segment of posterior lateral spinnerets very short, basal segment the longest. Carapace, palp and legs uniform brown, abdomen darker then carapace, without markings or color patterns (Figure 36).

\section{Etymology}

The species epithet is a noun in apposition referring to main Indian population of the region, which is also the name of the protected area (FLONA Carajás).

\section{Discussion}

The faunistic cave diversity in Brazil is well studied when compared to other countries in South America (Pinto-Da-Rocha 1995; Trajano and Bichuette 2009; Trajano et al. 2016). However, the high diversity in the Neotropics (Mittermeier et al. 1998; Lewinsohn and Prado 2005), and the taxonomic chaos of several invertebrate taxa are limiting factors toward a better knowledge of this fauna. Moreover, the high number of estimated caves (approximately 100,000 caves) (Auler et al. 2001) spread over the country, and occurring in distinct types of lithology, such as limestone, quartzite, arenite and ironstone (karstic areas), conceal an unquantifiable diversity yet to be discovered (Trajano and Bichuette 2009).

Epigean faunistic inventories for mygalomorphs in distinct regions of Brazil yielded similar diversities of families compared to our results. To date, the highest species diversity for mygalomorphs was found in National Forest of Caxiuanã (Floresta Nacional de Caxiuanã), in the Brazilian Amazon of the state of Pará (Bonaldo et al. 2009), where 42 species, belonging to seven families, were recorded. It is important to note that this survey used many distinct sampling methods and took place in a high diverse environment. Two other inventories that recorded mygalomorphs (Indicatti et al. 2008; Nogueira et al. 2014) that used few sampling methods yielded similar diversity to the present study (Table 1). When compared to epigean environments, caves are considered as oligotrophic, showing low complexity, high stability, and permanent absence of light (Poulson and White 1969), 
Table 1. List of four inventories, including mygalomorphs in distinct environments in Brazil. NMAS - nocturnal manual active searching, DMAS - diurnal manual active searching, BT - beating tray, $\mathrm{SN}$ - sweeping net, PT - pitfall trap, W - winkler extractor.

\begin{tabular}{|c|c|c|c|c|}
\hline Inventory & Study site & Bioma & $\begin{array}{c}\text { Richness } \\
\text { (species/families) }\end{array}$ & $\begin{array}{l}\text { Sampling } \\
\text { methods }\end{array}$ \\
\hline $\begin{array}{l}\text { Bonaldo et al. } \\
2009\end{array}$ & $\begin{array}{l}\text { FLONA Cax- } \\
\text { iuanã, PA, Brazil }\end{array}$ & Amazon & $42 / 7$ & $\begin{array}{l}\text { PT, BT, SN, } \\
\text { NMAS, W }\end{array}$ \\
\hline $\begin{array}{l}\text { Nogueira et al. } \\
2014\end{array}$ & $\begin{array}{l}\text { Pico da Neblina } \\
\text { National Park, } \\
\text { AM, Brazil }\end{array}$ & Atlantic Forest & $11 / 4$ & NMAS, BT \\
\hline $\begin{array}{l}\text { Indicatti et al. } \\
2008\end{array}$ & $\begin{array}{c}\text { CPCN Pró-Mata, } \\
\text { RS, Brazil }\end{array}$ & $\begin{array}{l}\text { Pine Forest } \\
\text { (Araucaria) }\end{array}$ & $12 / 5$ & PT \\
\hline Present study & $\begin{array}{c}\text { FLONA Carajás, } \\
\text { PA, Brazil }\end{array}$ & Amazon & $14 / 7$ & NMAS, DMAS \\
\hline
\end{tabular}

imposing limiting factors for the colonization by a significant amount of epigean species (Barr 1967).

The high percentage of juvenile specimens registered in the present survey was also found in other studies with hypogean spiders (Bernardi et al. 2007; Paquin and Dupérré 2009; Guadanucci et al. 2014; Mammola and Isaia 2016). Two distinct hypothesis can be considered to explain such pattern: (1) The high number of juveniles may suggest that some species could be using the hypogean environment as reproductive shelter. It was recently demonstrated that the European cave spider Meta menardi (Latreille, 1804) (Tetragnathidae) selects appropriate areas for the deposition of the egg sac, which is correlated with two environmental variables, airflow velocity and distance from the entrance (Chiavazzo et al. 2015), maintaining an optimal microclimate for the development of eggs and allowing the migration of the spiderlings outside the cave. Moreover, Guadanucci et al. (2014, 2016) reported the largest population of cave-dwelling mygalomorphs ( $T$. diamantina), where they found more than 100 spiders, among females and juveniles, what supports the idea of the cave as reproductive shelter. (2) Alternatively, and probably more plausible, the large quantity of juveniles present in caves may suggest the usage of such environment as refuge, where the immature spiders can find suitable abiotic conditions (stable temperatures and high humidity), microinvertebrates as food source and mainly low proportion of predators and/or competitors (Danielopol and Rouch 2012).

Judging from abundance and field observations, two of the 14 species examined seem to have a close ecological relation with the hypogean environment, and thus we classify them as troglophiles. These are G. metallophila n. sp. and H. aymara. Representatives of G. metallophila were very common in the caves in this particular region, occurring in fine substrate or underneath rocks, where they build their retreats. Although H. aymara was not as abundant as G. metallophila n. sp., considerable numbers of individuals were observed even using only active search as collecting method which usually does not yield many specimens. We could not identify any troglomorphic features in these two species, and we expect to find populations of such spiders in hypogean and epigean environments, which is the case of H. aymara.

The large theraphosids $N$. coloratovillosus, T. blondi and A. geniculata were recorded only from adult males during the wet season. Wandering males amplify their dispersal area when searching for females during reproductive season (Janowski-Bell and Horner 1999) and may be seen crossing roads and routes (Pérez-Miles et al. 2005). They probably came into the entrance zones of some caves by chance and were therefore recorded in the present inventory. Baerg (1958) suggests that large distance dispersion may result in reduced 
inbreeding and thus natural selection favors wandering males. Due to the low number of individuals recorded, we consider the remaining species as occasional visitors to these caves.

Spiders are common cave dwellers and were recorded in many inventories of hypogean environments (Trajano and Bichuette 2009; Cardoso 2012; Reddell 2012; Mammola and Isaia 2017). The number of records of mygalomorph species inhabiting caves has grown in the last years (Bernardi et al. 2007; Bertani et al. 2013; Bloom et al. 2014; Guadanucci et al. 2014, 2016; Maroquín 2014). Bloom et al. (2014) suggested that arachnids are one of the most important and common animals in cave environments, since they are predators. Mygalomorphae spiders act as medium to large predators in a resource-limited environment.

The southeastern state of Pará has already lost $53 \%$ of its original forest, and the remaining areas are extremely fragmented. The National Forest of Carajás and its neighboring protected areas are regarded as an "island of biodiversity", composing a great forest fragment of approximately $12,000 \mathrm{~km}^{2}$ (Martins et al. 2012). In this scenario, the association of distinct methods of environmental conservation, including sustainable usage of natural resources and the integral conservation (Tabarelli and Gascon 2005; Martins et al. 2012), may lead to the protection of a great number of iron caves as well as their epigean faunas, promoting the preservation of hypogean biodiversity.

\section{Acknowledgments}

We would like to thank Antonio Brescovit, curator of Instituto Butantan arachnid collection, for provinding repository for the type specimens, and the company Vale SA and Carste Science and Environment for the support during a field work.

\section{Disclosure statement}

No potential conflict of interest was reported by the authors.

\section{References}

Auler AS, Rubbioli E, Brandi R. 2001. As grandes cavernas do Brasil. Belo Horizonte: Grupo Bambuí de Pesquisas Espeleológicas. 227 p.

Ausserer A. 1871. Beiträge zur Kenntniss der Arachniden-Familie der Territelariae Thorell (Mygalidae Autor). Verhandlungen der Kaiserlich-Königlichen Zoologisch-Botanischen Gesellschaft in Wien. 21:117-224.

Ausserer A. 1875. Zweiter Beitrag zur Kenntniss der Arachniden-Familie der Territelariae Thorell (Mygalidae Autor). Verhandlungen der Kaiserlich-Königlichen Zoologisch-Botanischen Gesellschaft in Wien. 25:125-206.

Baerg WJ. 1958. The Tarantula. Lawrence: University of Kansas Press. 88 p.

Barr TC. 1967. Observations on the ecology of caves. American Naturalist. 101(922):475-491. doi: $10.1086 / 282512$

Barr TC, Holsinger JR. 1985. Speciation in Cave Faunas. Annual Review of Ecology and Systematics. 16(1):313-337. doi:10.1146/annurev.es.16.110185.001525

Bernardi LPO, Ferreira RL, Silva MS. 2007. Aspectos da ecologia de uma população de Lasiodora sp. (Araneae: Theraphosidae) em caverna granítica. Espeleo-Tema. 19:65-80.

Bertani R, Bichette ME, Pedroso DR. 2013. Tmesiphantes hypogeus sp. nov. (Araneae, Theraphosidae), the first troglobitic tarantula from Brazil. Anais da Academia Brasileira de Ciências. 85(1):107-115. doi:10.1590/S0001-37652013005000007

Bloom T, Binford G, Esposito LA, Garcia Ga, Perterson I, Nishida A, Loubert-Senear K, Agnarsson I. 2014. Discovery of two new species of eyeless spiders within a single Hispaniola cave. The Journal of Arachnology. 42(2):148-154. doi:10.1636/K13-84.1

Bonaldo Ab, Carvalho LS, Pinto-Da-Rocha R, Tourinho AL, Candiani DF, Lo-Man-Hung N, Abrahim N, Rodrigues BVB, Brescovit AD, Satirnino R, et al. 2009. Inventário e história natural 
dos aracnídeos da Floresta Nacional de Caxiuanã. In: Lisboa P, editor. Caxiuanã: desafios para a conservação de uma Floresta Nacional na Amazônia. Belém: Museu Paraense Emílio Goeldi; p. $545-588$.

Campos JF, Castilho A. 2012. Uma Visão Geográfica da Região da Flona de Carajás. In: Martins FD, Castilho AF, Campos JF, Hatano FM, Rolim SG, editors. Floresta Nacional de Carajás: Estudos sobre vertebrados terrestres. São Paulo: Nitro Imagens; p. 28-63.

Cardoso P. 2012. Diversity and community assembly patterns of epigean vs. troglobiont spiders in the Iberian Peninsula. International Journal of Speleology. 41(1):83-94. doi:10.5038/1827806X.41.1.9

Carmo FF, Jacobi CM. 2013. A vegetação de canga no Quadrilátero Ferrífero, Minas Gerais: caracterização e contexto fitogeográfico. Rodriguésia. 64(3):527-541.

Chiavazzo E, Isaia M, Mammola S, Lepore E, Ventola L, Asinari P, Pugno NM. 2015. Cave spiders choose optimal environmental factors with respect to the generated entropy when laying their cocoon. Scientific Reports. 5:1-8. doi:10.1038/srep07611

Christiansen K. 2012. Morphological adaptations. In: Culver DC, White WB, editors. Encyclopedia of caves. Amsterdam: Elsevier; p. 517-527.

Danielopol DLD, Rouch R. 2012. Invasion, active versus passive. In: Culver DC, White WB, editors. Encyclopedia of caves. Amsterdam: Elsevier; p. 404-409.

Dorr JN. 1964. Supergene iron ores of Minas Gerais, Brazil. Economic Geology. 59(7):1203-1240. doi:10.2113/gsecongeo.59.7.1203

Gertsch WJ. 1982. The troglobitic mygalomorphs of the Americas (Arachnida, Araneae). Bulletin of the Association for Mexican Cave Studies. 8:79-94.

Gibert J, Deharveng L. 2002. Subterranean ecosystems: a truncated functional biodiversity. BioScience. 52(6):473-481. doi:10.1641/0006-3568(2002)052[0473:SEATFB]2.0.CO;2

Goloboff PA. 1993. A reanalysis of mygalomorph spider families (Araneae). American Museum Novitates. 3056:1-32.

Guadanucci JPL, Braga PLM, Sá FS. 2014. Aspects of the activity rhythm and population size of troglophilic mygalomorph spiders (Trechona sp., Dipluridae) in a quartzite cave in Minas Gerais, Brazil. Journal of Natural History. 49(15-16):1-15. doi:10.1080/00222933.2014.946108

Guadanucci JPL, Fonseca-Ferreira R, Baptista RLC, Pedroso DR. 2016. An unusual new species of Trechona (Araneae: Mygalomorphae: Dipluridae), from quartzitic caves of the Diamantina Plateau, Minas Gerais, Brazil, with a key to the known species. Journal of Natural History. 50(39-40):2487-2497. doi:10.1080/00222933.2016.1193652

Hedin M, Bond JE. 2006. Molecular phylogenetics of the spider infraorder Mygalomorphae using nuclear rRNA genes (18S and 28S): conflict and agreement with the current system of classification. Molecular Phylogenetics and Evolution. 41(2):454-471. doi:10.1016/j.ympev.2006.05.017

Howarth FG. 1983. Ecology of cave arthropods. Annual Review of Entomology. 28(1):365-389. doi:10.1146/annurev.en.28.010183.002053

Indicatti RP, Lucas SM, Ott R, Brescovit AD. 2008. Litter dwelling mygalomorph spiders (Araneae: Microstigmatidae, Nemesiidae) from Araucaria forests in southern Brazil, with the description of five new species. Revista Brasileira de Zoologia. 25(3):529-546. doi:10.1590/ S0101-81752008000300021

Jacobi CM, Carmo FF. 2008. The contribution of ironstone outcrops to plant diversity in the iron quadrangle, a threatened Brazilian landscape. AMBIO: A Journal of the Human Environment. 37(4):324-326. doi:10.1579/0044-7447(2008)37[324:TCOIOT]2.0.CO;2

Janowski-Bell ME, Horner NV. 1999. Movement of the male brown tarantula Aphonopela hentzi (Araneae, Theraphosidae) using radio telemetry. The Journal of Arachnology. 27:503-512.

Juberthie C. 2000. The diversity of the karstic and pseudokarstic hypogean habitats in the world. In: Wilkens H, Culver DC, Humphreys WF, editors. Ecosystems of the world 30 subterranean ecosystems. Amsterdam: Elsevier; p. 17-39.

Lewinsohn TM, Prado PI. 2005. Quantas espécies há no Brasil? Megadiversidade. 1(1):36-42.

Mammola S, Isaia M. 2016. The ecological niche of a specialized subterranean spider. Invertebrate Biology. 135(1):20-30. doi:10.1111/ivb.12113

Mammola S, Isaia M. 2017. Spiders in caves. Proceedings of the Royal Society B. 284(1853):20170193. doi:10.1098/rspb.2017.0193

Maroquín JIM. 2014. Taxonomic revision of Hemirrhagus Simon, 1903 (Araneae: Theraphosidae, Theraphosinae), with description of five new species from Mexico. Zoological Journal of the Linnean Society. 170(4):634-689. doi:10.1111/zoj.12112 
Martins FD, Esteves E, Reis ML, Costa FG. 2012. Ações para Conservação. In: Martins FD, Castilho AF, Campos JF, Hatano FM, Rolim S, editors. Floresta Nacional de Carajás: Estudos sobre vertebrados terrestres. São Paulo: Nitro Imagens; p. 198-229.

Mittermeier RA, Myers N, Thomsen B, Da Fonseca GA, Olivieri S. 1998. Biodiversity hotspots and major tropical wilderness areas: approaches to setting conservation priorities. Conservation Biology. 12(3):516-520. doi:10.1046/j.1523-1739.1998.012003516.x

Moraes BC, Costa JMN, Costa ACL, Costa MH. 2005. Variação espacial e temporal da precipitação no estado do Pará. Acta Amazonica. 35:207-214. doi: 10.1590/S0044-59672005000200010

Nogueira A, Venticinque E, Brescovit AD, Lo-Man-Hung N, Candiani D. 2014. List of species of spiders (Arachnida, Araneae) from the Pico da Neblina, state of Amazonas, Brazil. Check List. 10(5):1044-1060. doi:10.15560/10.5.1044

Paquin P, Dupérré N. 2009. A first step towards the revision of Cicurina: redescription of type specimens of 60 troglobitic species of the subgenus Cicurella (Araneae: Dictynidae), and a first visual assessment of their distribution. Zootaxa. 2002:1-67.

Pedroso DR, Baptista RLC. 2014. A new troglomorphic species of Harmonicon (Araneae, Mygalomorphae, Dipluridae) from Pará, Brazil, with notes on the genus. Zookeys. 389:77-88. doi:10.3897/zookeys.389.6693

Pedroso DR, Baptista RLC, Bertani R. 2015. Anew species of Masteria (Araneae: Dipluridae: Masteriinae) from southeastern Brazil. Zoologia. 32(1):59-65. doi:10.1590/S1984-46702015000100009

Pérez-Miles F, Costa FG, Toscano-Gadea C, Mignone A. 2005. Ecology and behaviour of the 'road tarantulas' Eupalaestrus weijenberghi and Acanthoscurria suina (Araneae, Theraphosidae) from Uruguay. Journal of Natural History. 39(6):483-498. doi:10.1080/00222930410001671282

Petrunkevitch A. 1925. Arachnida from Panama. Transactions of the Connecticut Academy of Arts and Sciences. 27:51-248.

Pinto-Da-Rocha. 1995. Sinopse da fauna cavernícola do Brasil (1907-1994). Papéis Avulsos de Zoologia. 39:61-173.

Pipan T, Culver DC. 2012. Convergence and divergence in the subterranean realm: a reassessment. Biological Journal of the Linnean Society. 107(1):1-14. doi:10.1111/j.1095-8312.2012.01964.x

Poulson TL, White WB. 1969. The cave environment. Science. 165(3897):971-981. doi:10.1126/ science.165.3897.971

Reddell JR. 2012. Spiders and related groups. In: Culver DC, White WB, editors. Encyclopedia of caves. Amsterdam: Elsevier; p. 786-797.

Ribera C. 2004. Arachnida: Araneae (Spiders). In: Gunn J, editor. Encyclopedia of cave and karst science. New York, NY: Taylor \& Francis Books. 960 p.

Rolim SG, Couto HTZ, Jesus RM, França JT. 2006. Modelos volumétricos para a Floresta Nacional do Tapirapé-Aquirí, Serra dos Carajás (PA). Acta Amazonica. 36(1):107-114. doi:10.1590/ S0044-59672006000100013

Simmons GC. 1963. Canga Caves in the Quadrilátero Ferrífero, Minas Gerais, Brazil. The National Speleological Society Bulletin. 25:66-72.

Skirycz A, Castilho A, Chaparro C, Carvalho N, Tzotzos G, Siqueira JO. 2014. Canga biodiversity: a matter of mining. Frontiers in Plant Science. 5:1-9. doi:10.3389/fpls.2014.00653

Tabarelli M, Gascon G. 2005. Lessons from fragmentation research: improving management and policy guidelines for biodiversity conservation. Conservation Biology. 19(3):734-739. doi:10.1111/ j.1523-1739.2005.00698.x

Trajano E. 2012. Ecological classification of subterranean organisms. In: Culver DC, White WB, editors. Encyclopedia of caves. Amsterdam: Elsevier; p. 275-277.

Trajano E, Bichuette ME. 2009. Diversity of Brazilian subterranean invertebrates, with a list of troglomorphic taxa. Subterranean Biology. 7:1-16.

Trajano E, Gallão JE, Bichuette ME. 2016. Spots of high diversity of troglobites in Brazil: the challenge of measuring subterranean diversity. Biodiversity and Conservation. 25(10):1805-1828. doi:10.1007/s10531-016-1151-5

Trajano E, Moreira JDA. 1991. Estudo da fauna de cavernas da província espeleológica arenítica Altamira-Itaituba, Pará. Revista Brasileira de Biologia. 51(1):13-29.

World Spider Catalog. 2017. World spider catalog. Natural History Museum Bern, version 175[Internet]. [cited 2017 February 08]. Available from: https://wsc.nmbe.ch

Yamamoto FU, Brescovit AD. 2011. Descrição de quatro espécies novas de Idiops Perty, 1833 da região amazônica (Araneae, Idiopidae). In: III Congreso Latinoamericano de Aracnología. Montenegro, Quindío, Colombia. Memorias y Resúmeses. 192 p. 